\title{
The Effect of Minjingu Phosphate Rock and Triple Superphosphate on Soil Phosphorus Fractions and Maize Yield in Western Kenya
}

\author{
Robert Orangi Nyambati ${ }^{1}$ and Peter Asbon Opala ${ }^{2}$ \\ ${ }^{1}$ Kenya Forestry Research Institute, Maseno Regional Centre, P.O. Box 5199, Kisumu, Kenya \\ ${ }^{2}$ Department of Soil Science, Maseno University, P.O. Box, Private bag, Maseno, Kenya \\ Correspondence should be addressed to Robert Orangi Nyambati; nyambatir@yahoo.com
}

Received 29 November 2013; Accepted 1 January 2014; Published 4 March 2014

Academic Editors: J. A. Entry and W. Peijnenburg

Copyright (C) 2014 R. O. Nyambati and P. A. Opala. This is an open access article distributed under the Creative Commons Attribution License, which permits unrestricted use, distribution, and reproduction in any medium, provided the original work is properly cited.

\begin{abstract}
We tested the effects of triple superphosphate (TSP) and Minjingu phosphate rock (MPR), when applied at phosphorus (P) rates of 50 or $250 \mathrm{~kg} \mathrm{P} \mathrm{ha}^{-1}$ in a factorial combination with urea or Tithonia diversifolia green manure as nitrogen sources, on P availability and maize yields for two seasons at Nyabeda and Khwisero in Kenya. Phosphorus availability was determined by the Olsen method or sequential fractionation. There was no significant difference in Olsen P as influenced by TSP and MPR at $50 \mathrm{~kg} \mathrm{P}^{-1}$ irrespective of the $\mathrm{N}$ source at both sites in both seasons. However, at $250 \mathrm{~kg} \mathrm{Pha}^{-1}$, TSP gave significantly higher Olsen P than MPR. The labile $\mathrm{P}$ fractions generally followed the same trend as the Olsen P. Maize yields increased with increasing amount of P applied. Generally, there was no significant difference between TSP and MPR on maize yields irrespective of the N source. The Olsen-P, Resin-P, and sodium bicarbonate inorganic P correlated well with maize yields when TSP was used but the correlations between these P tests and maize yields for MPR were not consistent and therefore their use on soils treated with MPR should be exercised with caution.
\end{abstract}

\section{Introduction}

More than $80 \%$ of the soils in the densely populated highlands of western Kenya are inherently low in P and this seriously limits the productivity of maize which is the staple food crop in the area [1]. Although judicious application of inorganic $\mathrm{P}$ fertilizers is recognized as the most effective method for alleviating $\mathrm{P}$ deficiencies, their high cost, inaccessibility, and erratic and unprofitable crop responses limit their use, particularly on smallholder farms [2]. Much research on soil fertility management in western Kenya has therefore been devoted to testing nutrient inputs that are thought to be inexpensive, locally available, and sustainable, as alternatives to conventional fertilizers. The use of organic materials $(\mathrm{OMs})$ and phosphate rocks (PR) has in particular received considerable research attention in recent years [3-5]. This has been given impetus by a paradigm shift in soil fertility management towards the integrated soil fertility management (ISFM). In this strategy, the use of organic and inorganic nutrient sources in combination is advocated on smallholder farms [6] with the OMs being utilized mainly as sources of $\mathrm{N}$, because of their low $\mathrm{P}$ content, while inorganic fertilizers are used to supply P. In addition, to increase the range of OMs that smallholder farmers can use in integrated soil fertility management (ISFM), some nontraditional sources of nutrients such as agroforestry shrubs are being tested with Tithonia diversifolia green manure (tithonia) showing great promise [7]. The combination of OMs such as tithonia with inorganic $\mathrm{P}$ fertilizers is particularly attractive since it has been demonstrated to reduce $\mathrm{P}$ sorption and increase $\mathrm{P}$ availability in these P fixing soils [8].

Phosphorus when applied to the soil undergoes a series of reactions which transforms it to varying forms of availability to the plant. Determination of the available P usually employs extracting solutions which dissolve and remove specific forms of soil P from the solid phase. Currently the Olsen method is used to estimate inorganic $\mathrm{P}$ availability in acid soils of western Kenya but there are concerns that it may 
TABLE 1: Some selected chemical and physical characteristics of the soils at Nyabeda and Khwisero.

\begin{tabular}{lcc}
\hline Parameter & Nyabeda & Khwisero \\
\hline $\mathrm{pH}(1: 2.5$ soil : water) & 5.40 & 5.20 \\
Exchangeable acidity $\left(\mathrm{cmol}_{\mathrm{c}} \mathrm{k} \mathrm{g}^{-1}\right)$ & 0.10 & 1.00 \\
Organic carbon \% & 1.58 & 1.75 \\
Exchangeable $\mathrm{Ca}\left(\mathrm{cmol}_{\mathrm{c}} \mathrm{kg}^{-1}\right)$ & 4.65 & 3.53 \\
Exchangeable $\mathrm{Mg}\left(\mathrm{cmol}_{\mathrm{c}} \mathrm{kg}^{-1}\right)$ & 1.90 & 1.25 \\
Exchangeable $\mathrm{K}\left(\mathrm{cmol}_{\mathrm{c}} \mathrm{kg}^{-1}\right)$ & 0.09 & 0.07 \\
Olsen extractable P $\left(\mathrm{mg} \mathrm{kg}^{-1}\right)$ & 3.9 & 4.4 \\
P sorption at P conc. of $0.2 \mathrm{mg} \mathrm{P} \mathrm{L}$ & 316 & 375 \\
Clay (\%) & 55 & 35 \\
Sand (\%) & 25 & 45 \\
Silt (\%) & 20 & 20 \\
Textural class & Clay loam & Sandy clay loam \\
\hline
\end{tabular}

not accurately predict available $\mathrm{P}$ because it was originally developed for alkaline soils. In addition, when used with phosphate rock $(\mathrm{PR})$, it may not extract undissolved PR [9], which provides a significant, if not the main portion of $\mathrm{P}$, that is directly available to plants. Sequential chemical extraction procedures, on the other hand, are used to separate extractable soil $\mathrm{P}$ into different inorganic and organic fractions [10]. The underlying assumption in these approaches is that the readily available soil $\mathrm{P}$ is removed first with mild extractants, while the less available or plant unavailable $\mathrm{P}$ can only be extracted with stronger acids and alkalis. However, according to [11], methods of determination of available P, in an agronomic context, never measure the quantity of $\mathrm{P}$ available to the crop but measure a fraction of soil $\mathrm{P}$ that is somewhat related to that portion of soil $\mathrm{P}$ that is plant available. A knowledge of the relationships is useful for a better understanding of the capacity of $\mathrm{P}$ fractions to sustain an adequate supply of $\mathrm{P}$ to crops [12]. The objective of this study was therefore to (i) compare effect of two P sources, Triple superphosphate (TSP) and Minjingu phosphate rock (MPR) when applied with either urea or tithonia green manure on soil phosphorus fractions and maize yields, and (ii) determine the relationship between the $\mathrm{P}$ fractions and maize yields in acid soils of western Kenya.

\section{Materials and Methods}

2.1. Site and Soil Descriptions. A field experiment was conducted for two consecutive seasons from March 2007 to February 2008 at two sites in western Kenya, Nyabeda $\left(34^{\circ} 15^{\prime} \mathrm{E}, 020^{\prime} \mathrm{N}\right)$ which is an altitude of 1330 masl and Khwisero $\left(34^{\circ} 30^{\prime} \mathrm{E}, 07^{\prime} \mathrm{N}\right)$ which is at 1430 masl. Both sites receive a mean annual rainfall of $1800 \mathrm{~mm}$. The sites were chosen on the basis of contrasting soil characteristics (Table 1) with the soils at Khwisero being Acrisols while at Nyabeda they are Ferralsols.

The experiment was laid out as a randomized complete block design with four replications with plot sizes measuring $6 \mathrm{~m}$ by $6 \mathrm{~m}$. The treatments consisted of two P sources, TSP $(20 \% \mathrm{P})$ and MPR (13\% P), each applied at the rate of $50 \mathrm{~kg} \mathrm{Pha}^{-1}$ or $250 \mathrm{~kg} \mathrm{Pha}^{-1}$. The two $\mathrm{P}$ rates represent two different strategies of $\mathrm{P}$ application, a large one-time application $\left(250 \mathrm{~kg} \mathrm{Pha}^{-1}\right)$ that is expected to provide a strong residual effect for several cropping seasons of maize and seasonal applications of $50 \mathrm{~kg} \mathrm{P} \mathrm{ha}^{-1}$. These two $\mathrm{P}$ sources were combined with either urea or tithonia, which were applied seasonally to provide $\mathrm{N}$ at a rate of $60 \mathrm{~kg} \mathrm{ha}^{-1}$. In addition, a control treatment with no $\mathrm{P}$ input but with urea applied to supply $60 \mathrm{~kg} \mathrm{~N} \mathrm{ha}^{-1}$ and a tithonia alone treatment (tithonia applied at $1.82 \mathrm{tha}^{-1}$ to provide $60 \mathrm{~kg} \mathrm{~N} \mathrm{ha}^{-1}$ ) were included. Initial characterization of tithonia (consisting of leaves and tender stems) showed that, on average, it had $3.3 \% \mathrm{~N}, 0.30 \% \mathrm{P}$, and $4.0 \% \mathrm{~K}$. At the application rate of $60 \mathrm{~kg} \mathrm{Nha}^{-1}$, tithonia therefore also provided $6 \mathrm{~kg}$ of P. To ensure that the total $\mathrm{P}$ rates among treatments with urea and tithonia as $\mathrm{N}$ sources did not differ, TSP or MPR in the treatments with tithonia was therefore applied to supply only the difference required to provide the appropriate $\mathrm{P}$ rate. Potassium was blanket applied to all treatments at $60 \mathrm{~kg} \mathrm{ha}^{-1}$. The intention was to ensure that the other macronutrients were not limiting to plant growth while studying the P effects. The nutrient inputs were evenly spread within the appropriate experimental plots and incorporated to a depth of $0-0.15 \mathrm{~m}$ at the time of planting in each of the seasons, apart from MPR or TSP at the P rate of $250 \mathrm{~kg} \mathrm{ha}^{-1}$, which were applied in the first season only. However, only half of the urea was applied at planting and the rest was applied 5 weeks later. The experiment was run for two cropping seasons (March to August 2007 and September 2007 to February 2008). In both seasons, maize (Hybrid 511) was planted at a spacing of $0.75 \mathrm{~m}$ by $0.25 \mathrm{~m}$ and grown using the recommended agronomic practices of the area and its grain yield determined at the end of each season.

2.2. Soil Sampling and Analyses. In each season, soil samples $(0-0.15 \mathrm{~m})$ were collected in each plot at the ninth week after planting of the maize crop. Each soil sample was a composite collected from nine sampling points per plot. The soils were air-dried and prepared for analyses using standard procedures. The available soil $\mathrm{P}$ was determined using two methods, (i) the conventional Olsen method [13] in which available $\mathrm{P}$ was determined by shaking $2.5 \mathrm{~g}$ of air-dried soil with $50 \mathrm{~mL}$ of $0.5 \mathrm{M} \mathrm{NaHCO}_{3}$ (pH 8.5) for 30 minutes and the inorganic $\mathrm{P}$ in the extract determined colorimetrically, and (ii) sequential fractionation by the method of [10] in which the following $P$ fractions were determined: Resin extractable inorganic $\mathrm{P}$ (Resin- $\mathrm{P}_{\mathrm{i}}$ ), sodium bicarbonate extractable inorganic and organic $\mathrm{P}\left(\mathrm{NaHCO}_{3}-\mathrm{P}_{\mathrm{i}}\right.$ and $\left.\mathrm{NaHCO}_{3}-\mathrm{P}_{\mathrm{o}}\right)$, sodium hydroxide extractable inorganic and organic $\mathrm{P}\left(\mathrm{NaOH}-\mathrm{P}_{\mathrm{i}}\right.$ and $\mathrm{NaOH}-\mathrm{P}_{\mathrm{o}}$ ), and dilute hydrochloric acid extractable $\mathrm{P}(\mathrm{HCl}-$ $\left.\mathrm{P}_{\mathrm{i}}\right)$.

2.3. Mathematical Calculations and Data Analyses. The relative agronomic effectiveness (RAE) of MPR compared to TSP was calculated as

$$
\operatorname{RAE}=\frac{\left(Y_{\mathrm{MPR}}-Y_{\text {control }}\right)}{\left(Y_{\mathrm{TSP}}-Y_{\text {control }}\right)} \times 100,
$$


TABLE 2: Olsen extractable soil P $\left(\mathrm{mg} \mathrm{kg}^{-1}\right)$ at Nyabeda and Khwisero.

\begin{tabular}{|c|c|c|c|c|}
\hline \multirow{2}{*}{ Treatment } & \multicolumn{2}{|c|}{ Nyabeda } & \multicolumn{2}{|c|}{ Khwisero } \\
\hline & Season 1 & Season 2 & Season 1 & Season 2 \\
\hline (1) Control & 3.8 & 4.4 & 3.6 & 5.8 \\
\hline (2) Tithonia (6 kg P ha $\left.{ }^{-1}\right)$ & 4.0 & 4.9 & 4.3 & 6.1 \\
\hline (2) TSP + urea $\left(50 \mathrm{~kg} \mathrm{Pha}^{-1}\right)$ & 4.8 & 5.4 & 5.7 & 7.7 \\
\hline (3) $\mathrm{TSP}+$ tithonia $\left(50 \mathrm{~kg} \mathrm{P} \mathrm{ha}^{-1}\right)$ & 5.2 & 5.4 & 6.8 & 7.5 \\
\hline (4) MPR + urea (50 kg P ha $\left.{ }^{-1}\right)$ & 3.9 & 5.0 & 4.2 & 7.1 \\
\hline (5) MPR + tithonia (50 kg P ha $\left.{ }^{-1}\right)$ & 4.8 & 5.6 & 4.8 & 6.9 \\
\hline (6) TSP + urea $\left(250 \mathrm{~kg} \mathrm{P} \mathrm{ha}^{-1}\right)$ & 21 & 12 & 22 & 24 \\
\hline (7) $\mathrm{TSP}+$ tithonia $\left(250 \mathrm{~kg} \mathrm{P} \mathrm{ha}^{-1}\right)$ & 18 & 14 & 20 & 28 \\
\hline (8) MPR + urea $\left(250 \mathrm{~kg} \mathrm{Pha}^{-1}\right)$ & 7.7 & 9.0 & 9.4 & 16 \\
\hline (9) MPR + tithonia $\left(250 \mathrm{~kg} \mathrm{P} \mathrm{ha}^{-1}\right)$ & 8.0 & 11 & 10 & 16 \\
\hline s.e.d & 2.3 & 0.9 & 1.7 & 1.9 \\
\hline CV. & 11 & 8 & 13 & 10 \\
\hline
\end{tabular}

TSP: triple superphosphate; MPR: Minjingu phosphate rock; s.e.d.: standard error of difference between means; CV: coefficient of variance.

where $Y_{\mathrm{MPR}}$ is maize grain yield from MPR, $Y_{\mathrm{TSP}}$ is maize grain yield from TSP, and $Y_{\text {control }}$ is maize grain yield from control (0 P).

The Genstat statistical package [14] was used to conduct analysis of variance (ANOVA) to determine the effect of treatments on the soil $\mathrm{P}$ fractions and maize grain yields. The standard error of difference between means (s.e.d.) was used to compare the treatment means. Mention of statistical significance refers to $P<0.05$ unless otherwise stated. The relationships between relevant parameters were determined by using correlation analysis.

\section{Results}

3.1. Olsen $P$. The Olsen $P$ generally increased with increasing rates of $\mathrm{P}$ application (Table 2 ). There was no significant difference in Olsen $\mathrm{P}$ as influenced by TSP and MPR at the $\mathrm{P}$ rate of $50 \mathrm{~kg} \mathrm{ha}^{-1}$ irrespective of whether they were applied in combination with urea or tithonia at both sites in both seasons. However at P rate of $250 \mathrm{~kg} \mathrm{ha}^{-1}$, TSP gave significantly higher Olsen $\mathrm{P}$ values than MPR with same $\mathrm{N}$ source at both sites in both seasons. For the same $\mathrm{P}$ source, there was no significant effect of $\mathrm{N}$ source, that is, tithonia and urea on Olsen $\mathrm{P}$ in the first season at both sites. In the second season, however, combining TSP or MPR with tithonia generally gave higher Olsen $\mathrm{P}$ values than their respective combinations with urea. Between the sites, the Olsen $\mathrm{P}$ values were generally higher at Khwisero than Nyabeda for comparable treatments with the differences being more marked in the second season.

\subsection{Soil P Fractions}

3.2.1. Labile $P$ (Resin-P and Sodium Bicarbonate Inorganic and Organic $\mathrm{P}$ ). Both the resin- $\mathrm{P}$ and $\mathrm{NaHCO}_{3}-\mathrm{P}_{\mathrm{i}}$ were low and, on average, only $4 \%$ and $2 \%$ of the resin- $\mathrm{P}$ and $\mathrm{NaHCO}_{3}-\mathrm{P}_{\mathrm{i}}$ fractions, respectively, of the sequentially extracted $\mathrm{P}$ were recovered in these fractions (Tables 3, 4, 5, and 6). The addition of the $\mathrm{P}$ sources significantly increased the resin$\mathrm{P}$ and $\mathrm{NaHCO}_{3}-\mathrm{P}_{\mathrm{i}}$ values above the control at the higher $\mathrm{P}$ rates $\left(250 \mathrm{Kg} \mathrm{ha}^{-1}\right)$ but not the lower rates $\left(50 \mathrm{Kg} \mathrm{ha}^{-1}\right)$ in both seasons at both sites. At the higher $\mathrm{P}$ rate, there was no significant difference in resin- $\mathrm{P}_{\mathrm{i}}$ between TSP + urea and TSP + tithonia in the first season but, in the second season, TSP + tithonia was better than TSP + urea at both sites. But the difference between MPR combined with urea or tithonia was not significant at both sites in both seasons. The $\mathrm{NaHCO}_{3}$ $\mathrm{P}_{\mathrm{i}}$ followed the same trend as that of resin-P although its values were lower. In general, TSP had higher resin-P and $\mathrm{NaHCO}_{3}-\mathrm{P}_{\mathrm{i}}$ than MPR at both sites in both seasons at similar $\mathrm{P}$ application rates. Bicarbonate extractable $\mathrm{P}_{0}$ was higher than the resin- $\mathrm{P}$ and $\mathrm{NaHCO}_{3}-\mathrm{P}_{\mathrm{i}}$ in all the treatments at both sites at the two sampling times and represented an average of $11 \%$ (range $8-15 \%$ ) of the sum of the sequentially extracted $\mathrm{P}$ fractions and an average of $59 \%$ of the labile $\mathrm{P}$ fraction (Tables 4-6). However, the $\mathrm{NaHCO}_{3}-\mathrm{P}_{\mathrm{o}}$ was unaffected by treatments at both sites.

3.2.2. Moderately Labile $P\left(\mathrm{NaOH}-\mathrm{P}_{i}\right.$ and $\left.\mathrm{NaOH}-\mathrm{P}_{\mathrm{o}}\right)$ and Nonlabile $\mathrm{P}\left(\mathrm{HCl}-\mathrm{P}_{i}\right)$. The moderately labile fraction constituted $80 \%$ of the sequentially extracted $P$ that was recovered. There was no significant treatment effect on the moderately labile fraction at the lower $P$ rates at both sites in both seasons. However, at the high $\mathrm{P}$ rate, TSP applied in combination with urea gave higher $\mathrm{NaOH}-\mathrm{P}_{\mathrm{i}}$ than its combination with tithonia at Nyabeda in the first season (Table 3 ). The TSP treatments also gave higher $\mathrm{NaOH}-\mathrm{P}_{\mathrm{i}}$ than similar MPR treatments at the higher rate at Nyabeda in the first season. However, the difference between MPR applied in combination with urea and tithonia was not significant. A similar trend was observed at Khwisero in this season. In the second season, there was an increase in $\mathrm{NaOH}-\mathrm{P}_{\mathrm{i}}$ above the control for the lower $\mathrm{P}$ rate of $50 \mathrm{~kg} \mathrm{ha}^{-1}$ but this was not significant. A similar trend as in the first season whereby the TSP treatments gave higher $\mathrm{NaOH}-\mathrm{P}_{\mathrm{i}}$ than the MPR treatments at the higher $\mathrm{P}$ rate was observed at both sites although statistical significance was not 
TABLE 3: Sequentially extractable soil P fractions $\left(\mathrm{mg} \mathrm{kg}^{-1}\right)$ at Nyabeda in the first season.

\begin{tabular}{|c|c|c|c|c|c|c|c|}
\hline Treatment & Resin- $\mathrm{P}_{\mathrm{i}}$ & $\mathrm{NaHCO}_{3}-\mathrm{P}_{\mathrm{i}}$ & $\mathrm{NaOH}-\mathrm{P}_{\mathrm{i}}$ & $\mathrm{HCl}-\mathrm{P}_{\mathrm{i}}$ & $\mathrm{NaHCO}_{3}-\mathrm{P}_{\mathrm{o}}$ & $\mathrm{NaOH}-\mathrm{P}_{\mathrm{o}}$ & Sum of fractions \\
\hline (1) Control & 8.5 & 5.2 & 81 & 9.2 & 47 & 265 & 416 \\
\hline (2) Tithonia $\left(6 \mathrm{~kg} \mathrm{P} \mathrm{ha}^{-1}\right)$ & 8.5 & 5.6 & 75 & 9.2 & 44 & 274 & 416 \\
\hline (3) TSP + urea $\left(50 \mathrm{~kg} \mathrm{Pha}^{-1}\right)$ & 9.5 & 6.9 & 85 & 9.7 & 47 & 291 & 449 \\
\hline (4) TSP + tithonia $\left(50 \mathrm{~kg} \mathrm{P} \mathrm{ha}{ }^{-1}\right)$ & 9.6 & 8.6 & 77 & 9.7 & 44 & 268 & 417 \\
\hline (5) MPR + urea (50 kg Pha $\left.{ }^{-1}\right)$ & 8.4 & 6.2 & 76 & 8.2 & 43 & 285 & 427 \\
\hline (6) MPR + tithonia $\left(50 \mathrm{~kg} \mathrm{Pha}^{-1}\right)$ & 9.8 & 7.4 & 84 & 11 & 45 & 275 & 432 \\
\hline (7) TSP + urea $\left(250 \mathrm{~kg} \mathrm{Pha}^{-1}\right)$ & 28 & 27 & 143 & 9.6 & 46 & 281 & 535 \\
\hline (8) TSP + tithonia $\left(250 \mathrm{~kg} \mathrm{Pha}^{-1}\right)$ & 29 & 27 & 125 & 10 & 47 & 299 & 537 \\
\hline (9) MPR + urea $\left(250 \mathrm{~kg} \mathrm{Pha}^{-1}\right)$ & 27 & 14 & 99 & 11 & 43 & 288 & 483 \\
\hline (10) MPR + tithonia $\left(250 \mathrm{~kg} \mathrm{P} \mathrm{ha}^{-1}\right)$ & 26 & 16 & 103 & 12 & 44 & 268 & 469 \\
\hline s.e.d. & 5.1 & 2.1 & 10 & 0.63 & NS & NS & 18 \\
\hline $\mathrm{CV}$ & 11 & 8 & 13 & 12 & 10 & 11 & 7 \\
\hline
\end{tabular}

TSP: triple superphosphate; MPR: Minjingu phosphate rock; s.e.d.: standard error of difference between means; CV: coefficient of variance.

TABLE 4: Sequentially extractable soil P fractions $\left(\mathrm{mg} \mathrm{kg}^{-1}\right)$ at Khwisero in the first season.

\begin{tabular}{|c|c|c|c|c|c|c|c|}
\hline & Resin- $P_{i}$ & $\mathrm{NaHCO}_{3}-\mathrm{P}_{\mathrm{i}}$ & $\mathrm{NaOH}-\mathrm{P}_{\mathrm{i}}$ & HCl- $\mathrm{P}_{\mathrm{i}}$ & $\mathrm{NaHCO}_{3}-\mathrm{P}_{\mathrm{o}}$ & $\mathrm{NaOH}-\mathrm{P}_{\mathrm{o}}$ & Sum of fractions \\
\hline (1) Control & 7.4 & 7.4 & 72 & 9.4 & 57 & 322 & 475 \\
\hline (2) Tithonia & 8.4 & 7.7 & 72 & 10 & 56 & 398 & 522 \\
\hline (3) TSP + urea $\left(50 \mathrm{~kg} \mathrm{P} \mathrm{ha}^{-1}\right)$ & 11 & 9.2 & 72 & 10 & 52 & 327 & 481 \\
\hline (4) TSP + tithonia $\left(50 \mathrm{~kg} \mathrm{P} \mathrm{ha}^{-1}\right)$ & 15 & 11 & 84 & 10 & 57 & 329 & 506 \\
\hline (5) MPR + urea $\left(50 \mathrm{~kg} \mathrm{Pha}^{-1}\right)$ & 11 & 8.8 & 71 & 11 & 52 & 328 & 482 \\
\hline (6) MPR + tithonia $\left(50 \mathrm{~kg} \mathrm{P} \mathrm{ha}^{-1}\right)$ & 12 & 7.9 & 71 & 11 & 52 & 327 & 481 \\
\hline (7) TSP + urea $\left(250 \mathrm{~kg} \mathrm{Pha}^{-1}\right)$ & 43 & 25 & 135 & 12 & 57 & 356 & 628 \\
\hline (8) TSP + tithonia $\left(250 \mathrm{~kg} \mathrm{Pha}^{-1}\right)$ & 50 & 29 & 116 & 11 & 60 & 354 & 620 \\
\hline (9) MPR + urea $\left(250 \mathrm{~kg} \mathrm{P} \mathrm{ha}^{-1}\right)$ & 39 & 16 & 109 & 21 & 58 & 345 & 588 \\
\hline (10) MPR + tithonia $\left(250 \mathrm{~kg} \mathrm{P} \mathrm{ha}^{-1}\right)$ & 33 & 16 & 101 & 21 & 54 & 337 & 571 \\
\hline s.e.d. & 6.6 & 2.8 & 11 & 1.5 & NS & NS & 22 \\
\hline $\mathrm{CV}$ & 8 & 12 & 11 & 12 & 10 & 13 & 10 \\
\hline
\end{tabular}

TSP: triple superphosphate; MPR: Minjingu phosphate rock; s.e.d.: standard error of difference between means; CV: coefficient of variance.

always attained. The $\mathrm{NaOH}-\mathrm{P}_{\mathrm{o}}$ fraction was on average $60 \%$ of the sum of fractions (range 46-72\%) and constituted the largest of the $\mathrm{P}$ fractions in the studied soils but the difference in this $\mathrm{P}$ fraction among the treatments was not significant. The HCl- $\mathrm{P}_{\mathrm{i}}$ fraction was small and accounted for only $2 \%$ of the sum of all fractions. All treatments with MPR at the high $\mathrm{P}$ rate of $250 \mathrm{~kg} \mathrm{ha}^{-1}$ gave significantly higher $\mathrm{HCl}-\mathrm{P}_{\mathrm{i}}$ values than the control at Khwisero in both seasons while at Nyabeda only MPR applied in combination with tithonia at $250 \mathrm{~kg} \mathrm{P} \mathrm{ha}^{-1}$ had higher $\mathrm{HCl}-\mathrm{P}_{\mathrm{i}}$ values than the control in both seasons.

3.3. Maize Grain Yields. Maize strongly responded to application of $\mathrm{P}$ at both sites with yields generally increasing with increasing amount of $\mathrm{P}$ applied (Table 7$)$. Even tithonia applied alone $\left(6 \mathrm{~kg} \mathrm{Pha}^{-1}\right)$, more than doubled yields compared to the control at both sites in the two seasons. At the same $\mathrm{P}$ rate, there was no significant difference between TSP and MPR as $\mathrm{P}$ sources irrespective of whether tithonia or urea was used as $\mathrm{N}$ sources at Nyabeda in both seasons. At Khwisero, TSP was superior to MPR when tithonia was used as the $\mathrm{N}$ source, at similar $\mathrm{P}$ rates, in the first season. There were however no significant differences between MPR and
TSP, at same $\mathrm{P}$ rate, when urea was used at this site in the first season. In the second season, no significant differences were observed between TSP and MPR at similar P rates at Khwisero irrespective of the $\mathrm{N}$ source used. Among the $\mathrm{N}$ sources, tithonia and urea were equally effective at Nyabeda irrespective of $\mathrm{P}$ source or rate in the second season but, in the first season, TSP combined with urea at $250 \mathrm{~kg} \mathrm{ha}^{-1}$ was superior to tithonia at similar $\mathrm{P}$ rate. At Khwisero, tithonia was generally superior to urea in the second season. The RAE for MPR at Nyabeda ranged from 55\% to $113 \%$ (mean $83 \%$ ) while at Khwisero the RAE was higher with a range of $64 \%$ to $171 \%$ (mean $112 \%$ ). Generally combining MPR with tithonia gave a higher RAE at Nyabeda in the first season but at Khwisero combining it with urea gave higher RAE. In the second season however, combining MPR with tithonia consistently gave higher RAE than its combination with urea at both sites.

3.3.1. Relationships between Phosphorus Fractions with Maize Grain Yields. Olsen P correlated well with maize yields at Khwisero in both seasons while at Nyabeda the correlations were also significant except when MPR was used with urea or tithonia in the second season (Table 8). There were also 
TABLE 5: Sequentially extractable soil P fractions $\left(\mathrm{mg} \mathrm{kg}^{-1}\right)$ at Nyabeda in the second season.

\begin{tabular}{|c|c|c|c|c|c|c|c|}
\hline Treatment & Resin- $\mathrm{P}_{\mathrm{i}}$ & $\mathrm{NaHCO}_{3}-\mathrm{P}_{\mathrm{i}}$ & $\mathrm{NaOH}-\mathrm{P}_{\mathrm{i}}$ & HCl-P & $\mathrm{NaHCO}_{3}-\mathrm{P}_{\mathrm{o}}$ & $\mathrm{NaOH}-\mathrm{P}_{\mathrm{o}}$ & Sum of fractions \\
\hline (1) Control & 5.4 & 9.6 & 77 & 9 & 44 & 308 & 453 \\
\hline (2) Tithonia & 7.1 & 9.2 & 79 & 10 & 45 & 327 & 477 \\
\hline (3) TSP + urea $\left(50 \mathrm{~kg} \mathrm{Pha}^{-1}\right)$ & 9.8 & 11 & 91 & 11 & 46 & 324 & 493 \\
\hline (4) TSP + tithonia $\left(50 \mathrm{~kg} \mathrm{P} \mathrm{ha}^{-1}\right)$ & 8.1 & 10 & 84 & 9 & 44 & 317 & 472 \\
\hline (5) MPR + urea (50 kg P ha- $\left.{ }^{-1}\right)$ & 9.0 & 10 & 85 & 10 & 41 & 322 & 477 \\
\hline (6) MPR + tithonia $\left(50 \mathrm{~kg} \mathrm{P} \mathrm{ha}^{-1}\right)$ & 9.6 & 10 & 93 & 10 & 43 & 324 & 490 \\
\hline (7) TSP + urea $\left(250 \mathrm{~kg} \mathrm{Pha}^{-1}\right)$ & 33 & 21 & 143 & 11 & 44 & 333 & 585 \\
\hline (8) TSP + tithonia $\left(250 \mathrm{~kg} \mathrm{P} \mathrm{ha}^{-1}\right)$ & 40 & 23 & 135 & 10 & 44 & 331 & 582 \\
\hline (9) MPR + urea $\left(250 \mathrm{~kg} \mathrm{Pha}^{-1}\right)$ & 20 & 17 & 116 & 11 & 43 & 313 & 520 \\
\hline (10) MPR + tithonia $\left(250 \mathrm{~kg} \mathrm{P} \mathrm{ha}^{-1}\right)$ & 28 & 19 & 127 & 12 & 45 & 320 & 551 \\
\hline s.e.d. & 3.2 & 1.7 & 7.1 & 1.4 & NS & NS & 13 \\
\hline $\mathrm{CV}$ & 9 & 10 & 11 & 11 & 8 & 13 & 10 \\
\hline
\end{tabular}

TSP: triple superphosphate; MPR: Minjingu phosphate rock; s.e.d.: standard error of difference between means; CV: coefficient of variance.

TABLE 6: Sequentially extractable soil P fractions $\left(\mathrm{mg} \mathrm{kg}^{-1}\right)$ at Khwisero in the season.

\begin{tabular}{|c|c|c|c|c|c|c|c|}
\hline Treatment & Resin- $\mathrm{P}_{\mathrm{i}}$ & $\mathrm{NaHCO}_{3}-\mathrm{P}_{\mathrm{i}}$ & $\mathrm{NaOH}-\mathrm{P}_{\mathrm{i}}$ & HCl-P & $\mathrm{NaHCO}_{3}-\mathrm{P}_{\mathrm{o}}$ & $\mathrm{NaOH}-\mathrm{P}_{\mathrm{o}}$ & Sum of fractions \\
\hline (1) Control & 13 & 10 & 85 & 10 & 59 & 297 & 474 \\
\hline (2) Tithonia & 15 & 13 & 85 & 11 & 72 & 284 & 480 \\
\hline (3) TSP + urea $\left(50 \mathrm{~kg} \mathrm{Pha}^{-1}\right)$ & 15 & 12 & 106 & 10 & 63 & 295 & 501 \\
\hline (4) TSP + tithonia $\left(50 \mathrm{~kg} \mathrm{P} \mathrm{ha}^{-1}\right)$ & 17 & 12 & 103 & 10 & 58 & 298 & 498 \\
\hline (5) MPR + urea $\left(50 \mathrm{~kg} \mathrm{Pha}^{-1}\right)$ & 17 & 10 & 101 & 10 & 54 & 307 & 499 \\
\hline (6) MPR + tithonia $\left(50 \mathrm{~kg} \mathrm{P} \mathrm{ha}^{-1}\right)$ & 20 & 15 & 93 & 13 & 60 & 283 & 484 \\
\hline (7) TSP + urea $\left(250 \mathrm{~kg} \mathrm{Pha}^{-1}\right)$ & 46 & 30 & 158 & 13 & 76 & 288 & 611 \\
\hline (8) $\mathrm{TSP}+$ tithonia $\left(250 \mathrm{~kg} \mathrm{P} \mathrm{ha}^{-1}\right)$ & 59 & 38 & 165 & 12 & 78 & 300 & 652 \\
\hline (9) $\mathrm{MPR}+$ urea $\left(250 \mathrm{~kg} \mathrm{P} \mathrm{ha}^{-1}\right)$ & 46 & 23 & 134 & 20 & 62 & 293 & 578 \\
\hline (10) MPR + tithonia $\left(250 \mathrm{~kg} \mathrm{P} \mathrm{ha}^{-1}\right)$ & 44 & 24 & 145 & 24 & 67 & 323 & 641 \\
\hline s.e.d. & 6.5 & 3.2 & 13 & 2.1 & NS & NS & 25 \\
\hline $\mathrm{CV}$ & 8 & 10 & 12 & 10 & 8 & 11 & 9 \\
\hline
\end{tabular}

TSP: triple superphosphate; MPR: Minjingu phosphate rock; s.e.d.: standard error of difference between means; CV: coefficient of variance.

significant correlations between Resin- $\mathrm{P}_{\mathrm{i}}$ and maize yield in both seasons at both sites except when MPR was used in combination with tithonia in the both seasons at Nyabeda and in the second season at Khwisero. $\mathrm{NaHCO}_{3}-\mathrm{P}_{\mathrm{i}}$ followed a similar trend to that of Resin- $\mathrm{P}_{\mathrm{i}}$. The relationship of the grain yield with organic $\mathrm{P}$ fractions $\left(\mathrm{NaHCO}_{3}-\mathrm{P}_{\mathrm{o}}\right.$ and $\left.\mathrm{NaOH}-\mathrm{P}_{\mathrm{o}}\right)$ and the nonlabile fraction $\left(\mathrm{HCl}-\mathrm{P}_{\mathrm{i}}\right)$ was generally weak and not significant.

\section{Discussion}

The higher amounts of Olsen $\mathrm{P}$, resin- $\mathrm{P}_{\mathrm{i}}$, and $\mathrm{NaHCO}_{3}-\mathrm{P}_{\mathrm{i}}$ fractions from the application of TSP compared to MPR are ascribed to the higher solubility of TSP compared to MPR whose dissolution is usually slow [15]. The increase in resin$\mathrm{P}_{\mathrm{i}}$ concentration, even when the relatively insoluble MPR was applied, is attributed to the low $\mathrm{pH}$ of these soils (5.4 at Nyabeda and 5.2 at Khwisero) which are lower than the upper $\mathrm{pH}$ limit of 6.0 for PR dissolution [16]. The soils at these sites are therefore suitable for $\mathrm{P}$ replenishment using MPR. The higher magnitude of the increase in available $\mathrm{P}$ concentrations in the soil as influenced by addition of MPR at Khwisero than that at Nyabeda is likely due to a higher rate of dissolution of MPR in the Khwisero soil than in the Nyabeda soil, as the former was more acidic than the latter.

The $\mathrm{NaOH}-\mathrm{P}_{\mathrm{i}}$ concentrations significantly increased with the increase in the application rates of TSP and MPR at both sites, but the increase was higher for the TSP treatments than for the MPR treatments. TSP is very soluble and it might therefore have quickly been fixed and then transformed mainly into the NaOH- $\mathrm{P}_{\mathrm{i}}$ pool in these high $\mathrm{P}$ fixing soils. The $\mathrm{NaOH}-\mathrm{P}_{\mathrm{i}}$ fraction is a sink for soluble $\mathrm{P}$ sources and is the less readily available $\mathrm{P}$ that is associated with $\mathrm{Al}$ and $\mathrm{Fe}$ oxides that dominate Ferralsols and Acrisols such as those in this study. Similar findings were reported by [17] who found that the rate of increase in $\mathrm{NaOH}-\mathrm{P}_{\mathrm{i}}$ concentration in a high $\mathrm{P}$ fixing Acrisols was higher when the soils were treated with TSP compared with the time when the soils were treated with a PR. The failure of the lower $\mathrm{P}$ rates to significantly increase $\mathrm{P}$ availability is attributed to P-fixation and uptake by plants. At the higher $\mathrm{P}$ rates, most of the $\mathrm{P}$ fixation sites are quenched and the $\mathrm{P}$ buffer capacity exceeded 
TABLE 7: Effect of treatments on maize grain yield $\left(\mathrm{t} \mathrm{ha}^{-1}\right)$ at Nyabeda and Khwisero.

\begin{tabular}{lcccc}
\hline \multirow{2}{*}{ Treatment } & \multicolumn{3}{c}{ Nyabeda } & \multicolumn{2}{c}{ Khwisero } \\
& 1 & 2 & 1 & 2 \\
\hline (1) Control & 0.95 & 0.43 & 1.13 & 0.10 \\
(2) Tithonia & 2.21 & 0.76 & 2.87 & 0.57 \\
(3) TSP + urea $\left(50 \mathrm{~kg} \mathrm{P} \mathrm{ha}^{-1}\right)$ & 3.47 & 1.58 & 3.81 & 0.94 \\
(4) TSP + tithonia $\left(50 \mathrm{~kg} \mathrm{P} \mathrm{ha}^{-1}\right)$ & 3.69 & 1.35 & 4.34 & 1.59 \\
(5) MPR + urea $\left(50 \mathrm{~kg} \mathrm{P} \mathrm{ha}^{-1}\right)$ & 3.22 & 1.63 & 3.74 & 1.11 \\
(6) MPR + tithonia $\left(50 \mathrm{~kg} \mathrm{Pha}^{-1}\right)$ & 3.12 & 1.47 & 3.19 & 1.46 \\
(7) TSP + urea $\left(250 \mathrm{~kg} \mathrm{P} \mathrm{ha}^{-1}\right)$ & 6.49 & 2.95 & 5.00 & 1.71 \\
(8) TSP + tithonia $\left(250 \mathrm{~kg} \mathrm{P} \mathrm{ha}^{-1}\right)$ & 5.05 & 2.50 & 4.34 & 1.59 \\
(9) MPR + urea $\left(250 \mathrm{~kg} \mathrm{P} \mathrm{ha}^{-1}\right)$ & 4.03 & 2.28 & 5.34 & 2.02 \\
(10) MPR + tithonia $\left(250 \mathrm{~kg} \mathrm{P} \mathrm{ha}^{-1}\right)$ & 4.07 & 2.00 & 4.97 & 2.66 \\
s.e.d. & 0.50 & 0.37 & 0.61 & 0.25 \\
CV & 15 & 18 & 12 & 17 \\
\hline
\end{tabular}

TSP: triple superphosphate; MPR: Minjingu phosphate rock; s.e.d.: standard error of difference between means; CV: coefficient of variance.

and therefore the higher the amounts of $\mathrm{P}$ detected in soil solution [18]. The absence of major changes in the $\mathrm{HCl}$ $\mathrm{P}_{\mathrm{i}}$ fraction, other than the MPR treatments at the higher rates, is to be expected because the soils in this study were very acidic and this favours the formation of $\mathrm{Al}$ and $\mathrm{Fe} \mathrm{P}_{\mathrm{i}}$ compounds associated with the $\mathrm{NaOH}-\mathrm{P}_{\mathrm{i}}$ fraction, over the insoluble Ca-P compounds such as hydroxyapatite which dominate the HCl- $\mathrm{P}_{\mathrm{i}}$ fraction [19]. The higher $\mathrm{HCl}-\mathrm{P}_{\mathrm{i}}$ in the MPR treatments compared to TSP is an indication of its lower solubility since it represents the undissolved PR. This could however become available over time for plant use as indicated by our results which show that soils treated with MPR at a rate of $250 \mathrm{~kg} \mathrm{Pha}^{-1}$ maintained a significantly higher level of the available $\mathrm{P}$ fractions (resin- $\mathrm{P}_{\mathrm{i}}$ and $\mathrm{NaHCO}_{3}-\mathrm{P}_{\mathrm{i}}$ ) and maize yields than the control in the second season even though the MPR was applied only in the first season. Onetime application of high rates of fertilizer $\mathrm{P}$ inputs has been termed as the high-input strategy [20] and this increases the soil $\mathrm{P}$ capital that serves as a major sink for added $\mathrm{P}$ and gradually releases plant available $\mathrm{P}$ for several years. Our study was however terminated after only two seasons and so a firm conclusion on the ability of the $250 \mathrm{~kg} \mathrm{Pha}^{-1}$ to sustain yields compared to the seasonal application of $50 \mathrm{~kg} \mathrm{Pha}^{-1}$ cannot be made because five seasons would have been required to have the $\mathrm{P}$ rates of the two strategies (onetime application of $250 \mathrm{~kg} \mathrm{Pha}{ }^{-1}$ versus seasonal application of $50 \mathrm{~kg} \mathrm{Pha}^{-1}$ ) equal. Soil organic $\mathrm{P}$ fractions were largely unaffected by application of the inorganic $P$ sources and even tithonia green manure. This is consistent with other research using sequential extraction procedures on tropical soils [21]. Organic $\mathrm{P}$ is sensitive to microbial activity and has a fast turnover rate and hence is difficult to increase [22].

Without $\mathrm{P}$ application, but with urea as $\mathrm{N}$ source (control), maize grain yield averaged $<1.0 \mathrm{tha}^{-1}$. Such low maize grain yields are typical in this area, which has highly $\mathrm{P}$ deficient soils [20]. At both sites, the soils that received no $\mathrm{P}$ fertilizer had an Olsen $\mathrm{P}$ values of $<6 \mathrm{mg} \mathrm{kg}^{-1}$, which is below the critical $\mathrm{P}$ concentration of $10 \mathrm{mg} \mathrm{kg}^{-1}$ for maize [23]. The response to $\mathrm{P}$ was therefore expected. On the basis of soil P levels alone, the crop at Khwisero would be expected to perform better than at Nyabeda, which was the case in the first season. In the second season however, the poor rainfall could have limited the plants ability to utilize the available $\mathrm{P}$ optimally and thus Nyabeda with higher clay content is likely to have retained more water than the sandy soil at Khwisero. This could partially explain the poorer performance of maize at Khwisero compared to Nyabeda in this season. The variations in maize yields observed between the two seasons are attributed mainly to the differences in rainfall. In the first season, the rainfall was generally high $(>1000 \mathrm{~mm})$ and hence higher maize yields were obtained than in the second season when the rainfall was low $(<500 \mathrm{~mm})$ and poorly distributed. The similar yields obtained by tithonia as a source of $\mathrm{N}$ compared to urea suggest that tithonia can provide $\mathrm{N}$ as effectively as urea. This is attributed to tithonia's fast decomposition rate, hence its ability to mineralize $\mathrm{N}$ during the growing season [24]. Tithonia can therefore be used as a substitute for urea in integrated soil fertility management systems. The RAE of MPR in our study was generally high and is consistent with other studies in the area $[4,25]$ that have concluded that MPR is a reactive $\mathrm{PR}$ and is therefore suitable for direct application. The better performance of MPR at Khwisero than Nyabeda is consistent with the available $\mathrm{P}$ being higher at Khwisero due to higher dissolution of MPR occasioned by the lower $\mathrm{pH}$ at this site as earlier discussed.

There were good correlations obtained between the Olsen $\mathrm{P}$, Resin- $\mathrm{P}_{\mathrm{i}}$ and $\mathrm{NaHCO}_{3}-\mathrm{P}_{\mathrm{i}}$, and maize grain yields when TSP was used as the $\mathrm{P}$ source indicating that these fractions can be used to predict $\mathrm{P}$ availability to maize in these soils when TSP is used. But given that sequential fractionation is not easily amenable to routine analyses, Olsen $\mathrm{P}$ is an adequate test for evaluating plant available $\mathrm{P}$ from TSP in these soils. The correlations between these tests and grain yields for MPR treatments were not however consistent and therefore their use on soils treated with MPR especially when combined with tithonia should be exercised with caution. Although plants can only take up available $\mathrm{P}$, other fractions of $\mathrm{P}$, such as $\mathrm{NaOH}-\mathrm{P}_{\mathrm{i}}$, are also depleted due to crop growth [18]. This fraction of $\mathrm{P}$, though not readily available to plants, may replenish available $\mathrm{P}$ when depleted. This may explain some of the significant correlations obtained with the $\mathrm{NaOH}-\mathrm{P}_{\mathrm{i}}$. Though organic fractions were far greater than the available inorganic $\mathrm{P}$, they did not correlate with the maize yields. This is because $\mathrm{P}_{\mathrm{i}}$ is released into solution after mineralization of $\mathrm{P}_{\mathrm{o}}$ and could only contribute to maize uptake if availability coincided with the crops growing period [26], which is not usually easy to achieve. The organic P fractions are however an important source of $\mathrm{P}$ in low input systems that are common on smallholder farms [27] and application of organic materials that are likely to enhance the soil organic matter content should therefore be encouraged on smallholder farms. 
TABLE 8: Relationships between phosphorus fractions with maize grain yields at Nyabeda and Khwisero.

\begin{tabular}{|c|c|c|c|c|c|}
\hline \multirow{3}{*}{ Treatment } & \multirow{3}{*}{$\mathrm{P}$ fraction } & \multicolumn{2}{|c|}{ Nyabeda } & \multicolumn{2}{|c|}{ Khwisero } \\
\hline & & Season 1 & Season 2 & Season 1 & Season 2 \\
\hline & & \multicolumn{4}{|c|}{$R^{2}$} \\
\hline \multirow{7}{*}{$\mathrm{TSP}+$ Urea $^{\mathrm{a}}$} & Resin- $P_{i}$ & $0.74^{* * *}$ & $0.70^{* * *}$ & $0.54^{* *}$ & $0.40^{*}$ \\
\hline & $\mathrm{NaHCO}_{3}-\mathrm{P}_{\mathrm{i}}$ & $0.77^{* * *}$ & $0.50^{* *}$ & $0.62^{* *}$ & $0.43^{*}$ \\
\hline & $\mathrm{NaHCO}_{3}-\mathrm{P}_{\mathrm{o}}$ & ns & ns & ns & ns \\
\hline & $\mathrm{NaOH}-\mathrm{P}_{\mathrm{i}}$ & ns & $0.60^{* *}$ & $0.51^{* *}$ & $0.37^{*}$ \\
\hline & $\mathrm{NaOH}-\mathrm{P}_{\mathrm{o}}$ & ns & ns & ns & ns \\
\hline & $\mathrm{HCl}-\mathrm{P}_{\mathrm{i}}$ & ns & ns & ns & ns \\
\hline & Olsen $\mathrm{P}$ & $0.66^{* * *}$ & $0.45^{*}$ & $0.54^{* *}$ & $0.40^{*}$ \\
\hline \multirow{7}{*}{ TSP + Tithonia ${ }^{\mathrm{a}}$} & Resin- $P_{i}$ & $0.53^{* *}$ & $0.43^{*}$ & $0.48^{*}$ & $0.43^{*}$ \\
\hline & $\mathrm{NaHCO}_{3}-\mathrm{P}_{\mathrm{i}}$ & $0.44^{*}$ & $0.39^{*}$ & $0.45^{*}$ & $0.44^{*}$ \\
\hline & $\mathrm{NaHCO}_{3}-\mathrm{P}_{\mathrm{o}}$ & ns & ns & ns & ns \\
\hline & $\mathrm{NaOH}-\mathrm{P}_{\mathrm{i}}$ & $0.40^{*}$ & $0.41^{*}$ & $0.44^{*}$ & 0.29 \\
\hline & $\mathrm{NaOH}-\mathrm{P}_{\mathrm{o}}$ & ns & ns & ns & ns \\
\hline & $\mathrm{HCl}-\mathrm{P}_{\mathrm{i}}$ & ns & ns & ns & ns \\
\hline & Olsen P & $0.59^{* *}$ & $0.40^{*}$ & $0.55^{* *}$ & $0.50^{* *}$ \\
\hline \multirow{7}{*}{$\mathrm{MPR}+\mathrm{Urea}^{\mathrm{a}}$} & Resin- $\mathrm{P}_{\mathrm{i}}$ & $0.49^{*}$ & $0.53^{* *}$ & $0.74^{* * *}$ & $0.58^{* *}$ \\
\hline & $\mathrm{NaHCO}_{3}-\mathrm{P}_{\mathrm{i}}$ & ns & $0.39^{*}$ & $0.70^{* * *}$ & $0.58^{* *}$ \\
\hline & $\mathrm{NaHCO}_{3}-\mathrm{P}_{\mathrm{o}}$ & ns & ns & ns & ns \\
\hline & $\mathrm{NaOH}-\mathrm{P}_{\mathrm{i}}$ & $0.33^{*}$ & $0.51^{* *}$ & $0.51^{* *}$ & $0.49^{*}$ \\
\hline & $\mathrm{NaOH}-\mathrm{P}_{\mathrm{o}}$ & ns & ns & ns & ns \\
\hline & $\mathrm{HCl}-\mathrm{P}_{\mathrm{i}}$ & ns & ns & ns & ns \\
\hline & Olsen P & $0.50^{* *}$ & ns & $0.76^{* * *}$ & $0.53^{* *}$ \\
\hline \multirow{7}{*}{ MPR+ Tithonia ${ }^{a}$} & Resin- $P_{i}$ & ns & ns & $0.64^{* *}$ & ns \\
\hline & $\mathrm{NaHCO}_{3}-\mathrm{P}_{\mathrm{i}}$ & ns & ns & $0.67^{* *}$ & ns \\
\hline & $\mathrm{NaHCO}_{3}-\mathrm{P}_{\mathrm{o}}$ & ns & ns & ns & ns \\
\hline & $\mathrm{NaOH}-\mathrm{P}_{\mathrm{i}}$ & $0.39^{*}$ & ns & $0.36^{*}$ & ns \\
\hline & $\mathrm{NaOH}-\mathrm{P}_{\mathrm{o}}$ & ns & ns & ns & ns \\
\hline & $\mathrm{HCl}-\mathrm{P}_{\mathrm{i}}$ & ns & ns & ns & ns \\
\hline & Olsen P & $0.40^{*}$ & ns & $0.68^{* * *}$ & $0.48^{*}$ \\
\hline
\end{tabular}

${ }^{\mathrm{a}} \mathrm{P}$ fractions for $\mathrm{P}$ rates of 50 and $250 \mathrm{~kg} \mathrm{ha}^{-1}$ have been included in the analysis. ${ }^{*},{ }^{* *}$, and ${ }^{* * *}$ significance at $0.05,0.01$, and 0.001 probability levels, respectively; ns: not significant.

\section{Conclusion}

Phosphorus availability was influenced by $\mathrm{P}$ rate and source. There was no significant difference in Olsen $\mathrm{P}$ as influenced by TSP and MPR at the $\mathrm{P}$ rate of $50 \mathrm{~kg} \mathrm{ha}^{-1}$ irrespective of whether they were applied in combination with urea or tithonia at both sites in both seasons. However, at $\mathrm{P}$ rate of $250 \mathrm{~kg} \mathrm{ha}^{-1}$, TSP gave significantly higher Olsen $\mathrm{P}$ values than MPR. The labile P fractions generally followed the same trend as the Olsen P. Only the MPR treatments significantly increased the $\mathrm{NaOH}$ inorganic $\mathrm{P}$ above the control with no $\mathrm{P}$ input. The organic $\mathrm{P}$ fractions were not affected by treatments. Maize strongly responded to application of $\mathrm{P}$ at both sites with yields generally increasing with increasing amount of $\mathrm{P}$ applied. Generally, at the same $\mathrm{P}$ rate, there was no significant difference between TSP and MPR as P sources irrespective of whether they were combined with tithonia or urea. The relative agronomic effectiveness of MPR was high ( $83 \%$ at Nyabeda and $112 \%$ at Khwisero) suggesting that
MPR is suitable for direct application at these sites. Between the $\mathrm{N}$ sources, tithonia was as equally effective or in some cases better than urea in increasing maize yields. There were good correlations obtained between the Olsen P, Resin-P and $\mathrm{NaHCO}_{3}$ inorganic $\mathrm{P}$, and maize grain yields when TSP was used indicating that these fractions can be used to predict $\mathrm{P}$ availability to maize in these soils when TSP is the $\mathrm{P}$ source. But given that sequential fractionation is laborious and therefore not easily amenable to routine soil analyses, the Olsen $\mathrm{P}$ is an adequate test for evaluating plant available $\mathrm{P}$ from TSP in these soils. The correlations between these P tests and grain yields for MPR were however not consistent and therefore their use on soils treated with MPR especially when combined with tithonia should be exercised with caution.

\section{Conflict of Interests}

The authors declare that there is no conflict of interests regarding the publication of this paper. 


\section{Acknowledgments}

The authors are grateful to Robin Chacha, Samuel Kirui, and Augustine Wandabwa who assisted with soil analyses, V. Oeba for helping in statistical analyses, and Tom Ochinga for managing the field experiments. Financial support for this study was provided by KEFRI.

\section{References}

[1] B. Jama and P. van Straaten, "Potential of East African phosphate rock deposits in integrated nutrient management strategies," Annals of Brazilian Academy of Sciences, vol. 78, no. 4, pp. 781790, 2006.

[2] S. M. Nandwa and M. A. Bekunda, "Research on nutrient flows and balances in East and Southern Africa: state-of-the-art," Agriculture, Ecosystems and Environment, vol. 71, no. 1-3, pp. 518, 1998.

[3] P. A. Opala, J. R. Okalebo, and C. Othieno, "Comparison of effects of phosphorus sources on soil acidity, available phosphorus and maize yields at two sites in western Kenya," Archives of Agronomy and Soil Science, vol. 59, no. 3, 2013.

[4] S. T. Ikerra, E. Semu, and J. P. Mrema, "Combining Tithonia diversifolia and minjingu phosphate rock for improvement of $\mathrm{P}$ availability and maize grain yields on a chromic acrisol in Morogoro, Tanzania," Nutrient Cycling in Agroecosystems, vol. 76, no. 2-3, pp. 249-260, 2006.

[5] M. W. Waigwa, C. O. Othieno, and J. R. Okalebo, "Phosphorus availability as affected by the application of phosphate rock combined with organic materials to acid soils in western Kenya," Experimental Agriculture, vol. 39, no. 4, pp. 395-407, 2003.

[6] N. Sanginga and P. L. Woomer, Integrated Soil Fertility Management in Africa: Principles, Practices and Development Process, Tropical Soil Biology and Fertility Institute of the International Centre for Tropical Agriculture, Nairobi, Kenya, 2009.

[7] B. Jama, C. A. Palm, R. J. Buresh et al., "Tithonia diversifolia as a green manure for soil fertility improvement in western Kenya: a review," Agroforestry Systems, vol. 49, no. 2, pp. 201-221, 2000.

[8] G. Nziguheba, C. A. Palm, R. J. Buresh, and P. C. Smithson, "Soil phosphorus fractions and adsorption as affected by organic and inorganic sources," Plant and Soil, vol. 198, no. 2, pp. 159-168, 1998.

[9] A. A. Rivaie, P. Loganathan, J. D. Graham, R. W. Tillman, and T. W. Payn, "Effect of phosphate rock and triple superphosphate on soil phosphorus fractions and their plant-availability and downward movement in two volcanic ash soils under Pinus radiata plantations in New Zealand," Nutrient Cycling in Agroecosystems, vol. 82, no. 1, pp. 75-88, 2008.

[10] M. J. Hedley, J. W. B. Stewart, and B. S. Chauhan, "Changes in inorganic and organic soil phosphorus fractions induced by cultivation practices and by laboratory incubations," Soil Science Society of America Journal, vol. 46, no. 5, pp. 970-976, 1982.

[11] H. Tiessen and J. O. Moir, "Characterization of available P by sequential extraction," in Soil Sampling and Methods of Analysis, M. R. Carter, Ed., pp. 75-86, Lewis Publications, Boca Raton, Fla, USA, 1993.

[12] A. Samadi, "Contribution of inorganic phosphorus fractions to plant nutrition in alkaline-calcareous soils," Journal of Agricultural Science and Technology, vol. 8, pp. 77-89, 2006.

[13] S. R. Olsen, C. V. Cole, F. S. Watanabe, and L. A. Dean, "Estimation of available phosphorus in soils by extraction with sodium bicarbonate," U.S.D.A. Circular 939, 1954.
[14] GENSTAT, “The GenStat Teaching Edition,” GenStat Release 7. 22 TE, VSN International, 2010.

[15] S. H. Chien, W. R. Clayton, and G. M. McClellan, "Kinetic dissolution of phosphate rocks in soils," Soil Science Society of America Journal, vol. 44, pp. 260-264, 1980.

[16] R. E. White, "Recent developments in the use of phosphate fertilizer on New Zealand pastures," Journal of the Australian Institute of Agricultural Science, vol. 2, pp. 25-32, 1989.

[17] A. K. N. Zoysa, P. Loganathan, and M. J. Hedley, "Comparison of the agronomic effectiveness of a phosphate rock and triple superphosphate as phosphate fertilisers for tea (Camellia sinensis L.) on a strongly acidic Ultisol," Nutrient Cycling in Agroecosystems, vol. 59, no. 2, pp. 95-105, 2001.

[18] R. J. Buresh, P. C. Smithson, and D. T. Hellums, "Building soil phosphorus capital in Africa," in Replenishing Soil Fertility in Africa, R. J. Buresh, P. A. Sanchez, and F. Calhoun, Eds., pp. 114-149, Soils Science Society of America special publication, Madison, Wis, USA, 1997.

[19] F. Iyamuremye and R. P. Dick, "Organic amendments and phosphorus sorption by soils," Advances in Agronomy, vol. 56, pp. 139-185, 1996.

[20] P. A. Sanchez, K. D. Shepherd, M. J. Soule et al., "Soil fertility replenishment in Africa: an investment in natural resource capital," in Replenishing Soil Fertility in Africa, R. J. Buresh, P. A. Sanchez, and F. Calhoun, Eds., pp. 1-46, Soils Science Society of America special publication, Madison, Wis, USA, 1997.

[21] A. Paniagua, M. J. Mazzarino, D. Kass, L. Szott, and C. Fernandez, "Soil phosphorus fractions under five tropical agroecosystems on a volcanic soil," Australian Journal of Soil Research, vol. 33, no. 2, pp. 311-320, 1995.

[22] H. Tiessen, J. W. B. Stewart, and C. V. Cole, "Pathways of phosphorus transformations in soils of differing pedogenesis," Soil Science Society of America Journal, vol. 48, no. 4, pp. 853858, 1984.

[23] J. R. Okalebo, K. W. Gathua, and P. L. Woomer, Laboratory Methods of Soil and Plant Analysis. A Working Manual, TSBFCIAT, SACRED Africa, KARI, SSEA, Nairobi, Kenya, 2nd edition, 2002.

[24] C. N. Gachengo, C. A. Palm, B. Jama, and C. Othieno, "Tithonia and senna green manures and inorganic fertilizers as phosphorus sources for maize in Western Kenya," Agroforestry Systems, vol. 44, no. 1, pp. 21-36, 1998.

[25] P. K. Mutuo, P. C. Smithson, R. J. Buresh, and R. J. Okalebo, "Comparison of phosphate rock and triple superphosphate on a phosphorus- deficient Kenyan soil," Communications in Soil Science and Plant Analysis, vol. 30, no. 7-8, pp. 1091-1103, 1999.

[26] A. Abunyewa, E. K. Asiedu, and Y. Ahenkorah, "Fertilizer phosphorus fractions and their availability to maize on different land forms of vertisols in the coastal savanna zone of Ghana," West African Journal of Applied Ecology, vol. 5, pp. 63-73, 2004.

[27] P. A. Sánchez and J. G. Salinas, "Low-input technology for managing oxisols and ultisols in tropical America," Advances in Agronomy, vol. 34, pp. 279-406, 1981. 

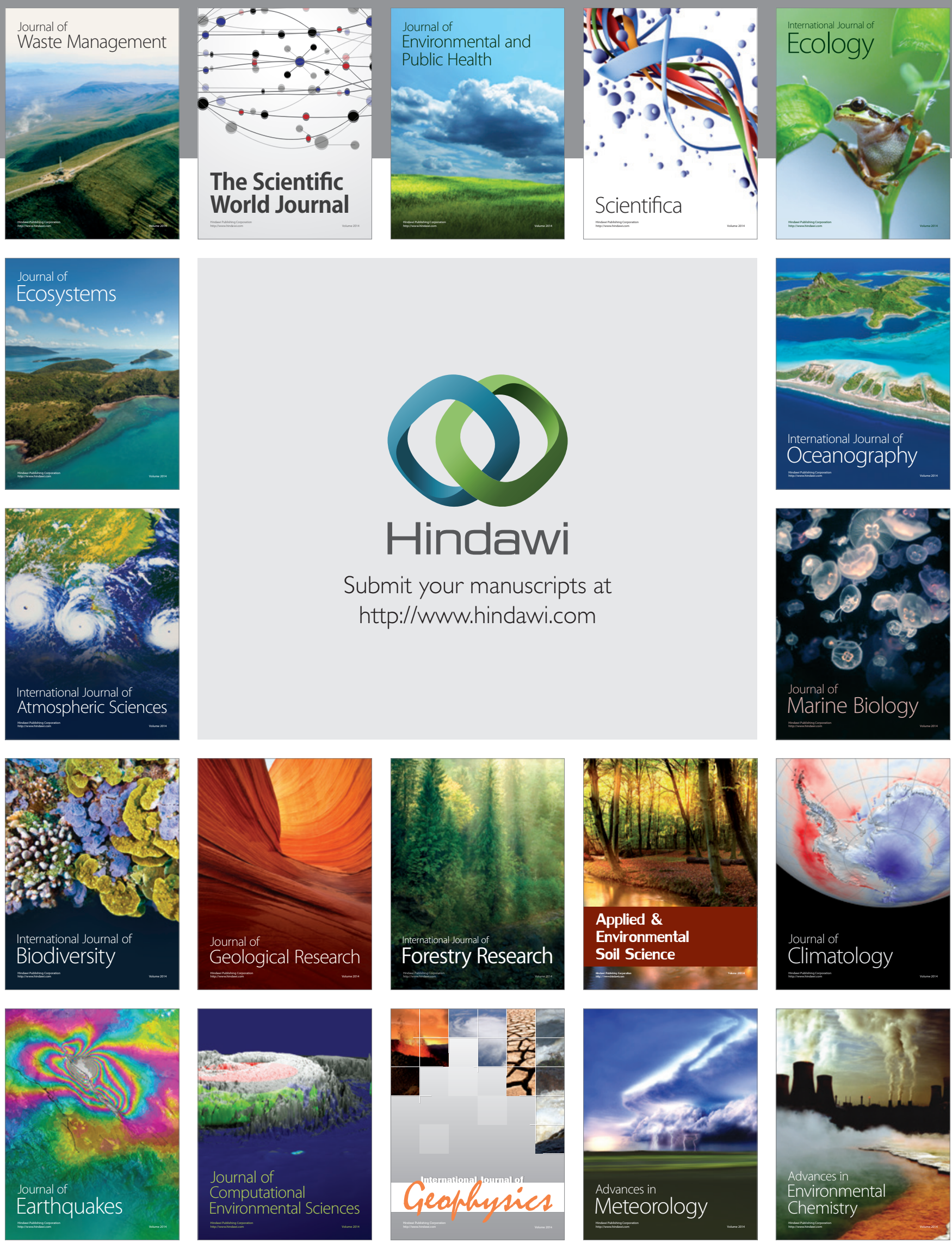